\title{
Pengaruh Persepsi Pembelajaran Housekeeping Terhadap Pemilihan Karir Bagi Siswa SMKN 3 Bogor
}

\author{
Ervina Taviprawati*, Vienna Artina Sembiring, Emenina Tarigan \\ Sekolah Tinggi Pariwisata Trisakti \\ *ervinataviprawati@stptrisakti.ac.id
}

\begin{abstract}
The research objective was to determine student responses about the career selection process. In this study using a descriptive method with a quantitative approach. The population in this study were students of SMK Negeri 3 Bogor, especially 85 students of the Hospitality Accommodation Skills Competency. The research was conducted in April-July 2015, with the time of distributing questionnaire numbers on 25-27 May 2015 at SMK Negeri 3 Bogor, having its address at Jalan Raya Pajajaran No. 84 RT 05/06, Babakan, Bogor Utara, West Java. The results of this study are students who learn housekeeping in their schools and have motivation to learn housekeeping in their schools, which greatly affects the lives of these students every day. Students who choose careers at home because they match their personalities can help these students get out of the crowd.
\end{abstract}

Keywords: Learning Perception; Students; Vocational High School; Housekeeping

\begin{abstract}
ABSTRAK
Tujuan penelitian ini untuk mengetahui tanggapan siswa mengenai proses pemilihan karir. Pada penelitian ini, menggunakan metode deskriptif dengan pendekatan kuantitatif. Populasi adalah siswa dari SMK Negeri 3 Bogor khususnya adalah 85 siswa Kompetensi Keahlian Akomodasi Perhotelan. Penelitian dilaksanakan pada bulan April-Juli 2015, dengan waktu penyebaran angka kuesioner pada tanggal 25-27 Mei 2015 yang bertempat di SMK Negeri 3 Bogor, beralamat di Jalan Raya Pajajaran No. 84 RT 05/06, Babakan, Bogor Utara, Jawa Barat. Hasil penelitian adalah siswa yang mempelajari Housekeeping disekolahnya dan memiliki motivasi untuk belajar Housekeeping disekolahnya hal terebut sangat mempengaruhi kehidupan siswa tersebut disetiap harinya. Siswa yang memilih berkarir di bidang Housekeeping karena sesuai dengan kepribadiannya dapat membantu siswa tersebut berinteraksi dengan orang banyak.
\end{abstract}

Kata Kunci : Persepsi Belajar; Siswa; Sekolah Menengah Kejuruan; Housekeeping 


\section{PENDAHULUAN}

Pariwisata merupakan salah satu aspek yang tidak akan pernah lepas dari Indonesia. Keberadaan pariwisata sangat erat dengan sosial budaya, penyediaan lapangan kerja, peningkatan taraf hidup rakyat serta gaya hidup yang semakin modern. Tercatat total wisatawan mancanegara yang berkunjung ke Indonesia dari 8.802.129 jiwa pada tahun 2013 meningkat sebesar 7.19 persen menjadi 9.4435.411 jiwa pada tahun 2014 (Badan Pusat Statistik, 2019).

Melihat perkembangan ini maka tidak luput dari tumbuh pesatnya industri hotel yang sangat erat sebagai salah satu sarana wisatawan yang berkunjung ke Indonesia. Dengan menjamurnya industri hotel tentunya seiring dengan ketersediaan lapangan pekerjaan yang ada. Badan Pusat Statistik (BPS) menyatakan terhidung pada tahun 2014 terdapat 1996 properti hotel berbintang yang tersebar di 33 provinsi di Indonesia dengan jumlah rata-rata 99,5 pekerja per hotelnya. Hal ini menandakan bahwa industri hotel merupakan faktor signifikan dari ketersediaan lapangan kerja khususnya bagi kesempatan untuk lulusan Sekolah Menengah Kejuruan (SMK) dengan label fresh graduate dalam memulai karirnya.

Namun pada kenyataannya, Badan Pusat Statistik mencatat berdasarkan pendidikan tertinggi yang ditamatkan, lulusan SMK banyak yang menjadi pengangguran. Jumlah lulusan SMK yang menganggur mencapai 813.776 jiwa atau 11,24 persen dari jumlah total pengangguran di Indonesia sampai Agustus 2014, yaitu 7,24 juta jiwa. Indikasi ini menunjukkan bahwa lulusan SMK terhambat oleh tuntutan industri dikarenakan pemilihan karir yang kurang matang ataupun bimbingan konseling yang tidak memadai sehingga lulusan SMK tidak siap terjun ke industri yang sesuai dengan latar belakangnya. Disamping itu juga terdapat persepsi ulusan SMK terhadap pembelajaran tertentu yang pada akhirnya tidak dikehendaki sehingga pemilihan karir
Vienna Artina Sembiring dan Emenina Tarigan) setelah lulus tidak sesuai dengan sasaran SMK pada bidangnya.

Salah satu SMK rumpun pariwisata khususnya perhotelan adalah SMK Negeri 3 Bogor. Dimana kompetensi keahlian akomodasi perhotelan hanya dimiliki oleh SMK Negeri 3 Bogor. Kompetensi keahlian Akomodasi Perhotelan memfokuskan kejuruan pada perhotelan khususnya divisi kamar hotel. Sehingga sasaran lulusan akomodasi perhotelan dapat menjadi tenaga kerja yang kompeten di departemen Front Office ataupun Housekeeping di hotel.

Namun seiring perkembangan waktu, kompetensi keahlian Akomodasi Perhotelan di SMKN 3 Bogor semakin diminati tetapi bukan menjadi pilihan utama sebagai pemilihan karir setelah lulus khususnya pada pembelajaran Housekeeping. Housekeeping adalah departemen dalam hotel yang bertugas membersihan, merapihkan, menjaga keindahan dan kenyamanan di seluruh area hotel, baik di luar gedung maupun di dalam gedung, termasuk kamar-kamar maupun ruangan-ruangan yang disewa oleh para tamu, restoran, office dan toilet (Rumekso, 2004). Housekeeping ini hanya dianggap sebagai salah satu syarat nilai yang harus dipenuhi dan batu loncatan untuk melanjutkan ke perguruan tinggi ataupun pilihan terakhir pada pemilihan karir (Sulastiyono, 2006). Siswa SMKN 3 Bogor menganggap pembelajaran housekeeping sangat erat kaitannya dengan pekerjaan kasar sehingga menciptaakan pencitraan yang buruk sebagai awal karir setelah lulus.

Di dunia perhotelan Housekeeping Department merupakan bagian yang penting dalam menjalankan operasional hotel terutama dibagian room (room section) karena pendapatan hotel yang paling utama adalah dari penjualan kamar sedangkan yang menyiapkan kebutuhan kamar merupakan tugas dari Housekeeping Department (Darsiah, 2019).

Pembelajaran kompetensi keahlian di SMK sangat menunjang 
pemilihan karir setelah lulus. Oleh karena itu SMKN 3 Bogor khususnya kompetensi keahlian AP memiliki mata pelajaran produktif yaitu housekeeping sebagai salah satu kompetensi keahlian yang wajib dipelajari sebagai syarat untuk lulus (Soegiyoharto, 2007).

\section{TINJAUAN PUSTAKA \\ Persepsi Pembelajaran}

Definisi mengenai persepsi dapat dilihat secara etimologis, persepsi atau dalam bahasa Inggris perception yang berasal dari bahasa Latin perceptio, dari percipere; yang artinya menerima atau mengambil. Persepsi dalam arti sempit adalah penglihatan, bagaimana cara seseorang melihat sesuatu; sedangkan dalam arti luas adalah pandangan atau pengertian, yaitu bagaimana seseorang memandang atau mengartikan sesuatu (Sobur, 2013).

Walgito (2010) menyatakan, persepsi adalah suatu proses yang didahului oleh proses penginderaan, yaitu merupakan proses diterimanya stimulus oleh individu melalui alat indera atau juga disebut proses sensoris.

Mulyana (2010) mengemukakan bahwa terdapat beberapa definisi lain dari persepsi diantaranya:

1. Brian Fellows, persepsi adalah suatu proses yang memungkinkan organisme menerima dan menganalisis informasi.

2. Kenneth K. Sereno dan Edward M. Bodaken, persepsi merupakan sarana yang memungkinkan kita memperoleh kesadaran akan sekeliling dan lingkungan kita.

3. Philip Goodacre dan Jennifer Follers, persepsi adalah merupakan proses mental yang digunakan untuk mengenali rangsangan.

4. Joseph A. DeVito, persepsi adalah suatu proses yang menjadikan kita sadar akan banyaknya stimulus yang mempengaruhi indera kita.

Persepsi dapat disebut sebagai inti komunikasi, karena jika persepsi kita tidak akurat, kita tidak mungkin berkomunikasi dengan efektif. Persepsi yang menentukan kita memilih suatu pesan dan mengabaikan pesan yang lain. Persepsi meliputi penginderaan atau sensasi melalui alat-alat indra kita (indra peraba, indra penglihat, indra pencium, indra pengecap dan indra pendengar), atensi dan interpretasi. Sensasi merupakan pesan yang dikirimkan ke otak lewat penglihatan, pendengaran, sentuhan, penciuman dan pengecapan. Reseptor indrawi mata, telinga, kulit, otot, hidung dan lidah, adalah penghubung antara otak manusia dan lingkungan sekitar (Mulyana, 2010).

\section{Faktor-Faktor Yang Mempengaruhi Persepsi}

Walgito (2010) memaparkan terdapat beberapa faktor yang berperan dalam persepsi yaitu:

1. Objek yang dipersepsi

Objek yang datang dari luar individu yang mempersepsi, dan dapat datang dari dalam diri individu yang bersangkutan.

2. Alat Indra

Alat-alat tubuh yang berfungsi mengetahui keadaan luar dapat juga dikatakan sebagai syaraf dan pusat susunan syaraf. Alat indra atau reseptor merupakan alat untuk menerima stimulus. Sebagai alat untuk mengadakan respon diperlukan syaraf motoris.

3. Perhatian

Merupakan langkah pertama sebagai suatu persiapan dalam rangka mengadakan persepsi yang merupakan pemusatan dari seluruh aktivitas individu yang ditujukan kepada sesuatu atau sekelompok objek.

Ada beberapa faktor yang berperan, agar terjadi persepsi, yaitu:

1. Objek atau stimulus yang dipersepsi

2. Alat indra dan syaraf-syaraf serta serta pusat susunan syaraf, yang merupakan syaraf fisiologis

3. Perhatian, yang merupakan syaraf psikologis.

Adapun menurut Sobur (2013), terdapat dua kumpulan faktor menentukan 
(Ervina Taviprawati, Vienna Artina Sembiring dan Emenina Tarigan) seleksi rangsangan, yaitu faktor intern, yang mengenainya, dan di sini terdiri dari:

1. Kebutuhan psikologis

berperannya perhatian.

2. Latar belakang

3. Pengalaman

4. Kepribadian

5. Sikap dan kepercayaan

6. Penerimaan diri.

terdiri dari:

Sedangkan faktor ekstern yang

1. Intensitas

2. Ukuran

3. Kontras

4. Gerakan

5. Ulangan

6. Keakraban

7. Sesuatu yang baru, hal-hal baru yang menarik perhatian.

Menurut Krech dan Crutchfield dalam Sobur (2013) faktor-faktor yang mempengaruhi persepsi seseorang dikategorikan menjadi:

1. Faktor fungsional yang dihasilkan dari kebutuhan, suasana hari, pelayanan dan pengalaman masa lalu seseorang.

2. Faktor struktural yang dihasilkan dari bentuk stimuli dan efek-efek netral yang ditimbulkan dari sistem syaraf individu.

3. Faktor situasional banyak berkaitan dengan bahasa non-verbal.

4. Faktor personal yang terdiri atas pengalaman, motivasi dan kepribadian.

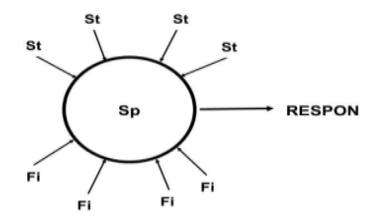

St $=$ stimulus (faktor luar)

= faktor intern (faktor dalam, termasuk perhatian)

$\mathrm{Sp}=$ struktur pribadi individu

Gambar 1 Proses Persepsi

Skema di atas merupakan gambaran bahwa individu menerima bermacam-macam stimulus yang datang dari lingkungan. Tidak semua stimulus dapat diperhatikan atau diberikan respon. Tidak semua stimulus akan diperhatikan atau akan diberikan respon. Individu mengadakan seleksi terhadap stimulus

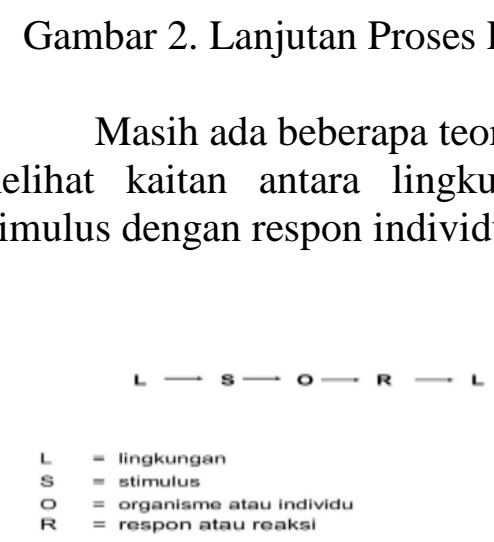

Gambar 3. Alternatif Proses Persepsi

Dalam skema tersebut terlihat bahwa organisme atau individu tidak berperan dalam memberikan respon terhadap stimulus yang mengenainya. Hubungan antara stimulus dengan respon bersifat mekanistis, stimulus atau lingkungan, sangat berperan dalam menentukan respon atau perilaku organisme. Pandangan yang demikian merupakan pandangan behavioristic. Pandangan ini berbeda dengan pandangan yang bersifat kognitif, yang memandang berperannya organisme dalam menentukan perilaku atau responnya.

\section{Defenisi Persepsi Pembelajaran}

Pembelajaran berasal dari kata belajar, yang dapat diartikan sebagai perubahan perilaku yang relatif tetap sebagai hasil adanya pengalaman. (Sobur, 2013). Belajar sebagai suatu perubahan yang relatif menetap dalam tingkah laku sebagai akibat atau hasil dari pengalaman yang lalu.

Morgan (dalam Sobur, 2013), 
pengertian persepsi belajar adalah suatu pandangan atau pengertian seseorang terhadap perubahan perilaku disebabkan pengalaman yang bisa mempengaruhi tingkah laku.

\section{Pengertian Pemilihan Karir}

Pemilihan karir menurut Sunarto dan Hartono (2006) adalah antara lain:

1. Faktor sosial ekonomi yang mencakup kemampuan ekonomi dan kondisi orang tua serta perekonomian suatu negara.

2. Faktor lingkungan mencakup lingkungan masyarakat, lingkungan kehidupan rumah tangga dan lingkungan teman sebaya.

3. Faktor pandangan hidup, seseorang yang berasal dari keluarga kurang mampu umumnya bercita-cita untuk memilih pekerjaan yang mendatangkan banyak uang.

Penentuan arah pilihan karir berasal dari sikap atau perilaku dari individu itu sendiri, selain itu individu mampu menentukan arah dan tujuan dalam kehidupan agar menjadi individu yang lebih baik dalam melaksanakan suatu pekerjaan (Taviprawati dan Sembiring, 2019).

\begin{tabular}{|l|l|}
$\begin{array}{c}\text { Persepsi } \\
\text { Pembelajaran } \\
\text { Housekeeping } \\
(\mathbf{X})\end{array}$ \\
$\begin{array}{l}\text { 1. Fungsional } \\
\text { 2. Personal } \\
\text { 3. Struktural } \\
\text { 4. Situasional }\end{array} \rightarrow$\begin{tabular}{l}
\multicolumn{1}{c|}{$\begin{array}{c}\text { Pemilihan Karir } \\
(\mathbf{Y})\end{array}$} \\
1. Faktor \\
Ekonomi \\
2. Faktor \\
Lingkungan \\
3. Faktor \\
Pandangan \\
Hidup
\end{tabular} \\
\hline
\end{tabular}

Gambar 4. Kerangka Pikir

\section{METODOLOGI PENELITIAN}

Dalam penelitian ini yang menjadi fokusnya adalah siswa yang menjalankan proses belajar mengajar di SMKN 3 Bogor mengenai penilaian persepsi pembelajaran housekeeping dan pengaruhnya terhadap keputusan pemilihan karir. Penelitian ini, menggunakan metode deskriptif dengan pendekatan kuantitatif (Santoso dan Tjiptono, 2001); (Sugiyono, 2014).
Populasinya adalah siswa dari SMK Negeri 3 Bogor khususnya adalah 85 siswa Kompetensi Keahlian Akomodasi Perhotelan. Penelitian dilaksanakan pada bulan April-Juli 2015, dengan waktu penyebaran angket kuesioner pada tanggal 25-27 Mei 2015 yang bertempat di SMK Negeri 3 Bogor, beralamat di Jalan Raya Pajajaran No. 84 RT 05/06, Babakan, Bogor Utara, Jawa Barat.

\section{HASIL DAN PEMBAHASAN}

\section{Gambaran Umum dan Obyek Penelitian}

Pada awalnya sekolah ini bernama SMKK Negeri Bogor dan telah diresmikan pada tanggal 12 Juni 1980 dan mengalami perkembangan serta perubahan nama didalamnya. Kemudian mengalami peningkatan dalam hal kualitas pengajaran, termasuk beberapa kali mengalami perubahan nama. Tahun 1999 berubah nama menjadi SMK Kelompok Pariwisata dengan Bidang Keahlian Pariwisata, Tata Busana dan Tata Kecantikan. Tetapi, setelah diberlakukan UU No.20 tentang Sisdiknas, nama sekolah berubah kembali menjadi SMK Negeri 3 Bogor, yang bertujuan untuk menyiapkan tenaga kerja yang siap bekerja dan menghasilkan lulusan yang siap dan mampu bekerja sesuai dengan kompetensi yang dimilikinya. Dan pada tahun 2006 SMK Negeri 3 Bogor membuka program keahlian baru yaitu Teknik Komputer Jaringan.

Secara umum SMK Negeri 3 Bogor memiliki tujuan yang sama dengan SMK lainnya yaitu meningkatkan, kecerdasan, pengetahuan, kepribadian, akhak mulia, serta keterampilan untuk hidup mandiri dan mengikuti pendidikan lebih lanjut sesuai dengan kejuruannya

\section{Data Responden Berdasarkan Usia dan Jenis Kelamin}

Responden yang berusia 15 tahun sebanyak 1 siswa $(1,2 \%)$, usia 16 tahun sebanyak 32 siswa $(37,6 \%)$ dan yang usia 17 tahun menunjukkan angka 
(Ervina Taviprawati, Vienna Artina Sembiring dan Emenina Tarigan)

paling tinggi yang didominasi sebanyak 52 siswa $(61,2 \%)$. Sedangkan responden berdasarkan jenis kelamin didominasi perempuan sebanyak 52 orang $(61,2 \%)$ dan responden laki-laki sebanyak 33 orang $(38,8 \%)$.

\section{Data Responden berdasarkan Domisili}

Karakteristik responden berdasarkan domisili atau tempat tinggal sebanyak 53 orang $(62,4 \%)$ berdomisili di Kotamadya Bogor, sebanyak 31 orang $(36,5 \%)$ berdomisili di Kabupaten Bogor dan sebanyak 1 orang $(1,2 \%)$ berdomisili di Kota Depok.

\section{Data Responden berdasarkan alasan masuk Akomodasi Perhotelan}

Responden berdasarkan alasan masuk Akomodasi Perhotelan karena minat sendiri sebanyak 69 orang $(81,2 \%)$; karena dorongan Orang Tua sebanyak 14 orang $(16,5 \%)$ dan sebanyak 2 orang (2,4\%) karena faktor lain.

\section{Tanggapan Siswa Mengenai Persepsi Pembelajaran Housekeeping}

Tanggapan siswa terhadap persepsi pembelajaran Housekeeping di SMKN 3 Bogor, menggunakan analisa statistik deskriptif dengan mencari mean pada setiap pernyataan yang berkaitan dengan Persepsi Pembelajaran. Dari 7 pernyataan yang valid dan hasil mean setiap mean pada pernyataan, dihasilkan 3,95 sebagai angka terendah dengan pernyataan "Mempelajari Housekeeping merupakan salah satu motivasi saya di Akomodasi Perhotelan", merupakan angka terendah dari akumulasi tiap pernyataan yang dikategorikan sebagai baik dan 4,48 sebagai angka tertinggi dengan pernyataan "Belajar Housekeeping sangat mempengaruhi kehidupan saya sehari-hari”, merupakan angka tertinggi dari akumulasi tiap pernyataan yang dikategorikan sebagai "Sangat Baik".
Tanggapan Siswa Mengenai Pemilihan Karir

Dari 10 pernyataan yang valid dan hasil mean setiap mean pada pernyataan, dihasilkan 3,36 sebagai angka terendah dengan pernyataan "Saya akan memilih berkarir di Housekeeping karena sesuai dengan kepribadian saya". Pada angka 3,36 menunjukkan pernyataan merupakan angka terendah dari akumulasi tiap pernyataan yang dikategorikan sebagai sedang. Sehingga kepribadian merupakan faktor terendah dari siswa untuk memilih berkarir di Housekeeping dan 4,25 sebagai angka tertinggi dengan pernyataan "Berkarir di Housekeeping dapat membantu saya berinteraksi dengan orang banyak" merupakan angka tertinggi dari akumulasi tiap pernyataan yang dikategorikan sebagai "Sangat Baik". Sehingga alasan utama siswa memilih berkarir di Housekeeping adalah agar dapat berinteraksi dengan orang banyak.

\section{Hubungan Persepsi Pembelajaran Terhadap Pemilihan Karir di SMKN 3 Bogor.}

Dalam menganalisa hubungan antara variabel independen persepsi pembelajaran dan variabel dependen pemilihan karir, menggunakan Pearson Product Moment. Terdapat hubungan positif diantara kedua variabel yang menunjukkan angka koefisien korelasi sebesar $\mathrm{r}=0,468$. Angka tersebut menunjukkan terdapat hubungan yang cukup atau sedang diantara kedua variabel tersebut.

\section{Pengaruh Persepsi Pembelajaran Housekeeping Terhadap Pemilihan Karir di SMKN 3 Bogor}

Untuk mengukur pengaruh persepsi pembelajaran terhadap pemilihan karir menggunaakan regresi linier sederhana, yang menampilkan estimasi koefisien dari variabel independen dan nilai signifikan.

Persepsi pembelajaran memiliki pengaruh positif terhadap pemilihan karir. Dapat dijelaskan melalui persamaan regresi linier sederhana sebagai berikut: 
$\mathrm{Y}=1,383+0,580 \mathrm{Y}$

Dari persamaan tersebut dapat dijelaskan bahwa:

1. Nilai konstanta yang dihasilkan sebesar 1,382 menunjukkan jika persepsi pembelajaran $(\mathrm{x})$ diasumsikan $=0$ maka skor pemilihan karir (y) sebesar 1,382.

2. Nilai koefisien regresi sebesar 0,580, yang berarti jika persepsi pembelajaran naik 1 satuan maka pemilihan karir yang relevan akan meningkat sebesar 0,580. Hasil koefisien yang positif menunjukkan adanya pengaruh yang positif dari persepsi pembelajaran terhadap pemilihan karir.

3. Koefisien Determinasi

\begin{tabular}{|c|c|c|c|c|}
\hline Model & $\mathrm{R}$ & $\mathrm{R}$ Square & $\begin{array}{c}\text { Adjusted } \\
\text { R Square }\end{array}$ & $\begin{array}{c}\text { Std.Error of } \\
\text { the Estimate }\end{array}$ \\
\hline 1 & $.468 \mathrm{a}$ & .219 & .209 & .41380 \\
\hline
\end{tabular}

Dari hasil perhitungan di atas terlihat hasil koefisien determinasi sebesar $21.9 \%$ yang mengukur tingkat pengaruh persepsi belajar terhadap pemilihan karir. Dan lainnya sebesar $78.1 \%$ dipengaruhi faktor lain diluar penelitian.

\section{KESIMPULAN DAN SARAN}

Siswa yang Mempelajari Housekeeping disekolahnya dan memiliki motivasi untuk belajar Housekeeping disekolahnya hal terebut sangat mempengaruhi kehidupan siswa tersebut disetiap harinya. Siswa yang memilih berkarir di bidang Housekeeping karena sesuai dengan kepribadiannya dapat membantu siswa tersebut berinteraksi dengan orang banyak.

SMKN 3 Bogor hendaknya mewadahi siswanya dengan kompetensi keahlian mereka melalui bimbingan konseling dan memotivasi serta meningkatkan kualitas pembelajaran khususnya untuk mata pelajaran Housekeeping. Selain itu mempertahankan kualitas kompetensi melalui sertifikasi dan pelatihan khusus bagi siswa amupun tenaga pendidiknya.

Kompetensi keahlian akomodasi perhotelan lebih memperhatikan potensi siswa, agar menanamkan moral budaya saing sesuai dengan kepribadiannya kelak di industri. Serta meningkatkan kerjasama dengan dunia industri untuk mempertahankan nama baik dan kesempatan berkarir bagi siswa.

\section{DAFTAR PUSTAKA}

Badan Pusat Statistik. (2019). Jumlah Wisatawan berkunjung ke Indonesia, Jumlah Akomodasi, Rata-rata Pekerja dan Jumlah Tamu per Hari Menurut Provinsi 2009-2014 (Hotel Bintang). Diakses pada tanggal 6 April 2019, dari http://www.bps.go.id/link Tabel Statis/view/id/1373.

Darsiah, A. (2019). Analisis Motivasi Belajar House Keeping Praktek Terhadap Prestasi Belajar Mahasiswa Sekolah Tinggi Pariwisata Trisakti. Jurnal Ilmiah Pariwisata, 25 (1): 32-43.

Mulyana, D. (2010). Ilmu Komunikasi Suatu Pengantar. Bandung: PT Remaja Rosdakarya.

Rumekso. (2004). Housekeeping Hotel. Yogyakarta: CV. Andi.

Santoso, S. \& Tjiptono, F. (2001). Riset Pemasaran: Konsep Aplikasi dengan SPSS. Jakarta: PT. Elex Media Komputindo.

Sobur, A. (2013). Psikologi Umum Dalam Lintas Sejarah. Bandung: Pustaka Setia.

Soegiyoharto, R. (2007). Peran Orang tua Terhadap Karir Anak. Diakses pada tanggal 23 Mei, dari 2019http://www1.bpkpenabur.or.id/ kps-jkt/wydiaw/55/artikel11.htm.

Sugiyono, (2014). Metode Penelitian Kuantitatif Kualitatif dan $R \& D$. Bandung: CV. Alfabeta.

Sulastiyono, A. (2006). Manajemen Penyelenggaraan Hotel, Seri Manajemen Usaha Jasa Sarana Pariwisata dan Akomodasi. Bandung: CV. Alfabeta.

Sunarto., \& Hartono, B. A. (2006). Perkembangan Peserta Didik. Jakarta: Rineka Cipta Wahjosumidjo. 
(Ervina Taviprawati, Vienna Artina Sembiring dan Emenina Tarigan)

Taviprawati, E., \& Sembiring, V. A.

(2019). Pengaruh Pengembangan

Karier Terhadap Kinerja Karyawan

Di Unit Tata Graha Hotel Menara

Peninsula. Jurnal Ilmiah

Pariwisata, 24 (3): 160-169.

Walgito, Bimo. (2010). Pengantar

Psikologi Umum. Yogyakarta: C.V

Andi. 